\title{
Challenges in Adopting Open Innovation Strategies in SMEs: An Exploratory Study in Portugal
}

\author{
Hakikur Rahman and Isabel Ramos \\ Centro Algoritmi, University of Minho, \\ Guimaraes, Braga, Portugal
}

hakik@dsi.uminho.pt iramos@dsi.uminho.pt

\begin{abstract}
Researches indicate that adoption of open innovation strategies in the entrepreneurships offers a promising way to face the ever increasing challenges due to globalization of entrepreneurships. However, in spite of abundance of researches, practices and case studies on adoption of open innovation strategies in relatively larger firms or corporate houses, studies are rare in the other sector of the entrepreneurships, which is popularly known as the small and medium scale enterprises (SMEs). This study has tried to find out the parameters of challenges that are being faced by the SMEs. A questionnaire has been placed on the Surveymonkey and a few selected companies were approached to participate in the web based survey. Due to the limitation of finding a larger contact list, this paper discusses about the findings of the completed survey, which is being termed as the pilot one. The findings are being discussed within the texts and it is expected that a new survey will start soon with a list containing larger number of companies.
\end{abstract}

Keywords: innovation, open innovation, open innovation strategy, SMEs, entrepreneurship.

\section{Introduction}

The evolution of the Internet technologies has allowed the small and medium scale enterprises (SMEs) to compete successfully and competently in both local and international markets (Schmid, Stanoevska-Slabeva and Tschammer, 2001). But in terms of adopting open innovation (OI) strategies, majority of them are facing challenges in many regions (Rahman, 2010), especially in the European region where over $99 \%$ of the enterprises are comprised of SMEs (European Commission, 2008). Further, it has been observed from other researches that despite OI's widespread applications, SMEs are struggling with its implementation due to their relatively low level of absorptive capacity, policy and financial constraints, and perceived management challenges (Van de Vrande et al., 2009; Saguy, 2011).

Material published as part of this publication, either on-line or in print, is copyrighted by the Informing Science Institute. Permission to make digital or paper copy of part or all of these works for personal or classroom use is granted without fee provided that the copies are not made or distributed for profit or commercial advantage AND that copies 1) bear this notice in full and 2) give the full citation on the first page. It is permissible to abstract these works so long as credit is given. To copy in all other cases or to republish or to post on a server or to redistribute to lists requires specific permission and payment of a fee. Contact Publisher@InformingScience.org to request redistribution permission.
The main aim of this research is to find a focus area to empower SMEs through adaptation of open innovation strategies. However, due to the open and collaborative nature of this newly evolved concept, the focus has been given to strategies belong to popularly known, open innovation, but not limited to other collaborative innovation, in spite of difficulties in putting any restrictive boundaries in between them. Further, due to the 
researchers' contemporary research environment, initial target area included a few selected SMEs in Portugal (main due to time, funding and networking), which has been expanded in a few other countries as the research grows. Similar surveys are being carried out in India, Israel, and Turkey through fellow research colleagues, who are trying to gather information in those countries and we like to make a comparative study based on the finding, which will be another research paper in near future.

For now to carry on this researches pertaining to the adoption of innovation strategies in Portugal, effort has been given to discuss some issues of innovation and open innovation in the area of business development, or enterprise development. We found researchers from various schools of thought have different opinion about defining business house, corporate business house, large business house, or even businesses belonging to small and medium scales. These we learned from reviewers' recommendations and remarks regarding development of the definition of enterprise during submission of our research papers in various journals and conference proceedings. To us, as long as the business brings out any value addition, either in terms of finance or knowledge, we are terming it as an enterprise which in the long run is beneficial to the community or society or nation or region. An enterprise in our view is an entity, who brings out value addition, either in terms of financial gain, or in terms of knowledge addition through any form of intervention, either products, processes, or services, or management orientations. Henceforth, a few points are being discussed on the effect of innovation, and especially open innovation strategies in the enterprise development.

\section{Innovation}

Innovation, being latent within the product, process and service in an enterprise as it grows naturally, and if these three could be intermingled further, such as incorporating new idea and changes through product, process and or service development, bond of innovation increases (Rahman \& Ramos, 2012a). In broad sense, there are quite a few means in the literature that support innovation in organizations (Caetano \& Amaral, 2011). In addition to the above three inherited parameters of an organization, due to the prevailing nature of innovation, often the entire organization may need to be manipulated, such as organizational reforms or organizational infrastructure management, and these would involve tools far beyond the control of the management of a single entity. They demand collaborative efforts of entities as a whole or individuals from different entities to act towards attaining the goal. However, thus going along, processes remain uncertain, especially looking into the very intricate nature of the business, and especially when the issue comes to the small and medium enterprises, where the decision making is very narrow as the ownermanager in almost in majority of the cases has to take care of each and every decision. Therefore, understanding of innovation tools is extremely important when researching for the benefit of the small scale enterprises.

Innovation is seen as the application of an idea or invention, technology or process to a product or process or service that satisfies a specific need and can be replicated at reduced cost. Further, as mentioned earlier, innovation creates value by playing a vital role in growth and social wellbeing. Thus, innovation acts as a significant driving force and provides unique opportunity to address global economic pressure, unstable economic markets, accelerated exponential growth of scientific knowledge and technological complexity, including new consumer needs and new market expectations (Saguy, 2011). However, it is a continuous process within the enterprise, including academics, researcher, and practitioners to follow up the entire life cycle management.

\section{Open Innovation}

In defining openness, Chesbrough (2003, p. XXIV) emphasizes on using of external ideas as well as internal ideas through internal and external paths to the market by taking the advantage of their 
technology. This definition of openness, though the most commonly used in the literature, but we find it as a broad one, which underscores the valuable ideas that emerge from among within (from inside or outside of the firm) and can be commercialized. Dahlander and Gann (2010) argue in favor of this concept with four reasoning. Firstly, the concept reflects social and economic changes in working patterns, where professionals seek portfolio careers rather than a job-for-life with a single employer. Hence, firms may need to find new ways of accessing talent from outside that might not wish to be employed exclusively and directly. Secondly, globalization has expanded the extent of the market that allows for an increased division of labor. Thirdly, due to the availability of new technologies the market institutions have improved through instruments like intellectual property rights (IPR), venture capital (VC), and at the same time, other technology standards allow for organization to trade ideas (such as licensing in or out). Fourthly, new technologies also allow for new ways to collaborate, coordinate or co-create across geographical distances.

Furthermore, due to the recent economic crisis, environmental challenges, diminishing resources, and the exponentially accelerating pace of technology and knowledge advancement, the open innovation proliferation call for not only the ideation of arena within the enterprises, but also requires a deep assessment of collaborators like academic, researchers, practitioners, and intermediaries with the collaborator-and-industry relationships (Saguy, 2011). Hence, recent thinking on open innovation and development of business eco-systems in this knowledge-based economy stresses the importance of external knowledge sources in stimulating innovation (Young, HewittDundas, \& Roper, 2008; Rahman \& Ramos, 2012b).

Open innovation has been a key trend in both innovation practice and research (Fu, 2012), and there has been substantial research on the elements of open innovation and their impact on firms' innovation performance (Chesbrough, 2003; 2006; Enkel, Gassmann, \& Chesbrough, 2009; Dahlander \& Gann, 2010). Open innovation is seen as a contributor to better innovation performance as measured by parameters like, innovative sales or number of patents (Laursen \& Salter, 2006; Rohrbeck, Hölzle, \& Gemünden, 2009; Chiang \& Hung, 2010; Lee, Park, Yoon \& Park, 2010; Huang, 2011).

However, little has been known about the wider effects of open innovation beyond its direct effect upon firms' innovation output in terms of sustained socio-economic development (Fu, 2012). Further, as mentioned, being mostly driven by small number of staffs and in lack of scarce resources, small and medium scale business firms are not aware of many other issues, like intellectual property right, venture capital, joint collaboration, trademark, copyright, or patenting. These are popularly applied open innovation instruments in large or corporate business sectors, but hardly been applied to this business sector.

By taking these intricate, but essential components of open innovation, this study has carried out a pilot survey among some selected firms in Portugal, tried to map their position in adopting OI strategies, and learning from their feedback likes to establish hypotheses on their adoption of OI strategies and the effect on these firms. If required, these firms will be given necessary consultation through an online portal and in the longer run interactive collaborative group may be created focusing sustained value addition. In addition, with the assistance of fellow colleagues, similar surveys are being carried out in a few countries to make a comparison and further extended research.

\section{Theoretical Framework}

Given the conceptual contexts above concerning the adoption of open innovation strategies by the SMEs not going further into more theoretical perspectives, this section goes directly towards the core aspect of the research and discusses the perceived parameters in terms of adopting open in- 
novation strategies utilizing ICTs, in the context of Portugal, and in general a few issues of challenges in other European Region.

\section{SMEs in Portugal}

SMEs are extremely essential to the economy of any country whether developed or developing, and they play a crucial role in economic development (Kapurubandara \& Lawson, 2006). However, it is always difficult to define SMEs, as they vary from countries to countries (Peres and Stumpo, 2000). In China, manufacturing SMEs are those with fewer than 2000 employees, or an annual turnover of less than or equal to RMB Yuan 300 million, or total assets of less than or equal to RMB Yuan 400 million (2-3). In India, the term small scale industries (SSIs ${ }^{\mathrm{i}}$ ), is a more familiar term than the SMEs and is based upon investment in assets ${ }^{\mathrm{ii}}$ (Saini \& Budhwar, 2008). However, despite various liberalizations and schematic changes to meet the emerging challenges of the business sector, availability of finance continues to be a major problem for small enterprises. Realizing this fact, some of the development financial institutions (DFIs) and forward looking commercial banks have put in operation a number of innovative schemes, and among them the Small Industries Development Bank of India (SIDBI) has taken the lead. The majority of the experiments have started showing good results, and the SSI sector plays a significant role in the Indian economy (Rahman \& Ramos, 2012c). In USA, the Small Business Administration sets the definition of small business based on criteria like, industry, ownership structure, revenue and number of employees (U.S. Small Business Administration, n.d.).

In Europe, there are three broad parameters that are being used to define SMEs, such as: microentities are companies with up to 10 employees; small companies employ up to 50 workers, whilst medium-sized enterprises have up to 250 employees. SMEs are also being defined as companies with either revenues of $€ 10-50$ million and, or a balance-sheet total of $€ 10-43$ million (European Commission, 2003). For ready reference, the exact definition of the European Commission is being cited below:

\begin{tabular}{|l|}
\hline 'The category of micro, small and medium-sized enterprises (SMEs) is \\
made up of enterprises which employ fewer than 250 persons and which \\
have an annual turnover not exceeding 50 million euro, and/or an annual \\
balance sheet total not exceeding 43 million euro.' (Extract of Article 2 of \\
the Annex of European Commission Recommendation 2003/361/EC, pp. 5.) \\
\hline
\end{tabular}

Following the definition of the European Commission, this study has considered the following criteria to define the SMEs in Portugal (see Table-1).

Table-1: Definition of SMEs (adopted from European Commission, 2003)

\begin{tabular}{|l|l|}
\hline Micro Enterprises & Enterprises with fewer than 10 employees \\
\hline Small Enterprises & $\begin{array}{l}\text { Enterprises with in between } 10 \text { and } 49 \text { em- } \\
\text { ployees }\end{array}$ \\
\hline Medium-sized Enterprises & $\begin{array}{l}\text { Enterprises with in between } 50 \text { and } 249 \text { em- } \\
\text { ployees }\end{array}$ \\
\hline
\end{tabular}

In 2008, there were 349756 and in 2009 there were 348552 SMEs in Portugal, representing $99.7 \%$ of the total companies of the non-financial business sector and around $59 \%$ of the turnover (Statistics Portugal, 2010; 2011). According to Statistics Portugal (2011), there is a $0.3 \%$ decrease in the number that shows the scenario of the economic crisis. However, in terms of exporting SMEs in Portugal $10 \%$ of the operating SMEs contributed over 30\% in either turnover and in $\mathrm{GVA}_{\mathrm{fc}}$. We find that the turnover suffered the highest percentage of fall at around $8 \%$. Hence, while mapping, we have emphasized on the turnover of the surveyed companies. At the same 
time, to learn about their pattern of investment, we have included a question about whether they have introduced any new products in their product line within the last two years.

\section{Constraints of Open Innovation in SMEs}

Despite being an important driver of innovation, technology based SMEs suffer from acute technology commercialization barriers. Though SMEs often partner with intermediaries to commercialize their technologies externally to compensate this form of barriers, there are other forms of barriers that this study has observed. Literature review reveals involvements of intellectual property (IP) brokers, venture capitalists, and technology trading platforms (Morgan and Crawford, 1996; Elton, Shah and Voyzey, 2002; Smallbone, North and Vickers, 2003; Lichtenthaler, 2005; Chesbrough, 2006; Gredel, Kramer, \& Bend, 2011), but apart from them there are a few other constraints has been categorized in four aspects as mentioned above, such as human aspects, constraints in general and related to policies, and constraints that have evolved due to increased globalization and competition. Table-2 shows those constraints in four categories, which are being described next.

Table-2: Open innovation constraints in SMEs.

\begin{tabular}{|c|c|c|c|}
\hline Human aspects & General constraints & Policy constraints & Competition \\
\hline Scarcity of skilled manpower & $\begin{array}{l}\text { Lack of market demand (Low } \\
\text { purchasing power of customer) }\end{array}$ & High cost of open innovation & Increase quality of product/service \\
\hline Scarcity of non-skilled manpower & Lack of skilled manpower & Lack of financing & Increase product differentiation \\
\hline Low image of the profession & Too expensive manpower & High economic risk & Look for market niches (demand) \\
\hline Low image of the sector & $\begin{array}{l}\text { Lack of quality management } \\
\text { personnel }\end{array}$ & Organizational ngidities & Increase marketing activity \\
\hline Low image of the type of enterpinse & $\begin{array}{l}\text { Problems with administrative } \\
\text { regulations }\end{array}$ & Government regulations & Reduce costs of production \\
\hline Wage levels too expensive & $\begin{array}{l}\text { Problems with infrastructure (e.g., } \\
\text { electricity, gas, communication, etc.) }\end{array}$ & Lack of customers' responsiveness & Forming strategic partuerships \\
\hline Unpleasant work & $\begin{array}{l}\text { Problems with access to finance } \\
\text { (other than interest rates) }\end{array}$ & $\begin{array}{l}\text { Lack of knowledge to use new } \\
\text { technology }\end{array}$ & $\begin{array}{l}\text { Reduce prices (prices of } \\
\text { products/services) }\end{array}$ \\
\hline Unpleasant working conditions & High interest rates & Lack of information on market & Increase working hours \\
\hline \multirow[t]{4}{*}{ No problem with recruiting } & $\begin{array}{l}\text { Lack of knowledge in implementing } \\
\text { new form of technology }\end{array}$ & \multirow[t]{4}{*}{ Did not have any innovative plan } & Look for other foreign markets \\
\hline & $\begin{array}{l}\text { Lack of knowledge in implementing } \\
\text { new form of organization }\end{array}$ & & \multirow[t]{3}{*}{ Reduce production } \\
\hline & $\begin{array}{l}\text { Difficult to protect intellectual } \\
\text { property }\end{array}$ & & \\
\hline & $\begin{array}{l}\text { Did not have any open innovation } \\
\text { plan }\end{array}$ & & \\
\hline
\end{tabular}

\section{Human Aspects}

In a classical paper, Tushman and Nadler (1986) identified that visionary leadership is an important factor that affect whether an organization realizes benefits from innovation. In 2012 Ashurst, Freer, Ekdahl, and Gibbons (2012) emphasize on Tushman and Nadler's argument that organizations can gain competitive advantage only by managing effectively for today, but at the same time by creating innovation for tomorrow and further advocate that within the enterprises, there is perhaps no more pressing managerial problem than the sustained management of innovation. 
In the contemporary market, the industry is always changing, depending on the demand and supply. In terms of innovation, patents may expire in due period or trademarks get updated in due course, or intellectual property rights need appropriate measure to update, thus exposing the firm to huge challenges. Furthermore, open innovation may not be driven by scale or process, but rather by breakthrough science, or a better understanding of human dynamics by validating new targets, which may be totally new to the market. Hence, the open innovation business models must be updated dynamically to fit into the new realities, which is extremely challenging for SMEs (Jaruzelski \& Dehoff, 2008; Rahman, 2010), and the role of skill manpower is particularly essential to compete and survive. This study places nine variables to learn the behavior of the surveyed firms in facing challenges of human aspects (see Table-3).

\section{General Constraints}

Referring contemporary studies Abulrub and Lee (2011) argues that the degree of open innovation depends on four environmental factors, such as the industry type (manufacturing industry, or service industry), the company size (large company, or SMEs), the technology intensity (hightech industry, or low-tech industry), and the market type (foreign markets, or domestic markets). However, when one searches about specific challenges associated to SMEs development utilizing open innovation, investigations are scarce and lead to scant human resources, misaligned consistency in the information about OI strategies, unawareness among SMEs about the actual benefit of open innovation, and foremost, incompetency in handling intricate knowledge resources that are being treated as OI tools in the evolving information era.

This research observes that apart from human aspects, there are three other aspects within the constraints that an enterprise faces during the business process. They are general constraints, policy related constraints and constraints that could be generated due to global competition. However, to go beyond the generalized concepts of constraints, and to learn about constraints related to adoption of open innovation strategies, this research has added several variables in the questionnaire (see Table-3). Somehow, they complement each other, but eventually the finding will be able to lead this research to focus on specific area of interventions to improve their performances. (Adopted from Flash Eurobarometer; SME Observatory Survey- Fieldwork: NovemberDecember 2006, Q16, 17, 21; Community Innovation Survey 2006-2008; this post doctoral research).

\section{Policy Constraints}

Though the management challenges for SME managers (mostly owner-manager) are quite different from the managers of large firms, but it is an uncharted area of investigation (Chesbrough, Vanhaverbeke, \& West, 2006). Similarly, the proximity of universities, research labs, large companies and lead users may play important role in the deployment of open innovation in the neighborhood SMEs. Additionally, an innovation policy fostering transactions between these innovation partners may also play a significant role in the evolution process (Van de Vrande, de Jong, Vanhaverbeke, \& de Rochemont, 2008).

As it means, open innovation is a paradigm that assumes that enterprises can and should use both external and internal ideas and paths to the market, when enterprises look to discover and realize any innovative opportunities. Further, the open paradigm assumes that internal ideas may also be taken to markets through external channels, outside the current businesses of the enterprise, to generate value. Hence, the OI model does not completely upset the traditional policymaking to legitimize policy interventions relevant to open innovation, such as spillovers, system failures and market failures (De Jong, Vanhaverbeke, Kalvet \& Chesbrough, 2008). In this aspect, this research has selected a few variables (see Table-3) to find out the pattern of challenges that the SMEs are facing in terms of policy constraints. 


\section{Competition}

The success factor in establishing a company is the capacity to create an organization that finds premium acceptance in the market. The entrepreneur that achieves success is one who meets the conditions in terms of the motivational and exogenous factors, in addition to market or technology opportunity (Cardoso, Roldão, Espanha, \& Castro, 2009). Further, in the era of globalization, and the evolution of Internet technologies enterprises have become much more competitive than ever before. Hence, firms have to keep track of elements not within the entities or local situations, but knowledge of global or regional market is essential even to keep up with the local market.

In a world of transformation, globalization and competition, innovating is no more a luxury, but an essentiality. To compete and survive, all businesses need to innovate, despite its various forms or norms, from the steady refinement of an established product to the leap in the unknown when an untried idea is launched and exposed to the outside world (Rahman, 2010). To measure the competitiveness among the surveyed SMEs in terms of competition ten variables have been chosen (see Table-3). Henceforth, the research methodology is being discussed.

\section{Research Methodology}

Broad objectives of this study are to acquire knowledge about the current status of SMEs active in open innovation practices in Portugal. The focus is to know the general and financial characteristics of the enterprises belonging to this category, and learn about their inclusion in open innovation paradigm in terms of financial, technological, managerial, policy issues and other relevant contexts. This survey could lead to;

- $\quad$ know about the actual state of affairs in the business sector focusing SMEs,

- foster understanding of developments taking place in various sectors of SMEs in business development within the country,

- analyze basic characteristics of those enterprises,

- acquire knowledge on best practices on open innovation,

- identify and recommend the best practices for policy makers and other beneficiaries,

- write a report justifying those analysis to bring up a coherent environment conducive to open innovation at national context, and

- put forward recommendations suggesting efforts and activities to resolve impediments of open innovation.

A few specific objectives are to know the:

- Turnover and investment patterns on open innovation;

- Human resource problem (skills, recruitment, etc.) related to implementation of open innovation strategies;

- Constraints on business and policy issues, and issues related to competition impending open innovation; and

- Issues on adoption or utilization of open innovation strategies.

\section{Research Approach}

Similar surveys are being carried out periodically among several European countries under the 'Observatory of European SMEs' project by the DG Enterprise and Industry and coordinated by the Eurobarometer Team of the European Commission. Analytical and technical reports of those surveys provide valuable insight about the SME community within the EU, but specifically to learn about their natures and contexts related to open innovation, further research need to be carried out. For this reason, to obtain in-depth and exhaustive information about the SMEs in Portugal, this survey would be effective and important. Researchers will be able to learn about the basic characteristics of SMEs, and at the same time could find out specific patterns and perspec- 
tives of SMEs in Portugal using/ adopting open innovation strategies. This would lead this research to prepare framework of recommendations that would be beneficial to the entrepreneurs, policy initiators and agencies acting in this sector. This research could provide tools for internal and external validation in formulating conceptual and business model.

\section{Survey Instrument}

The survey is being conducted using web based questionnaires placed on Surveymonkey (Attached in the Appendix). For the benefit of the local community, it has been translated in Portuguese, with the English version. Initially obtaining a readymade list of contacts from the group leader, individual emails with the survey link are being sent as the pilot phase. After obtaining responses, other forms of survey instruments, such as group administered questionnaire and household drop-off survey may be included depending on the nature and test result of the pilot survey. Further, it is intended that based on the survey responses and findings, interview may also be added into the survey.

\section{Data Collection Techniques}

Currently, the selected list of email addresses is being used to send the web link. However, in future, the following data collection techniques will be used; and

- depending on the sample size and scope of research, stratified, systematic and cluster sampling techniques may be used in the survey (Stratified sampling technique will be preferred),

- secondary data sources or archived data may also be used to measure validity of the hypotheses.

\section{Data Analysis Techniques}

Based on the nature of data accumulation, the following techniques may be used (in the pilot survey, descriptive statistics has been used due to low number of data);

- Descriptive statistics (measures of central tendency and dispersion), and inferential statistics (Hypotheses testing and Modeling),

- Post-stratification weights will be used to restore any artificially distorted proportions according to company size and industry sector.

\section{Evaluation of Data}

With very small data at hand, simple descriptive evaluation has been carried out. During the full phase of the survey, both formative and summative evaluation techniques will be applied, as the survey questionnaires have been designed based on past surveys of similar nature (though not specifically) and archived results may be used to generalize hypotheses of this research.

\section{Secondary Analysis}

With the same survey questionnaire, efforts are being given to conduct similar web based survey in other countries, such as India, Israel, and Turkey through fellow research colleagues. These joint research participants may apply the knowledge obtained from the evaluation to write scientific articles after secondary analyses on the SME population and relevant topics on innovation based on the data set, including comparative studies.

\section{Mapping of Present Scenario}

This study sets to examine the characteristics of SMEs on the basis of a questionnaire based survey of 20 companies from a selected list of 70 companies. Among them 19 emails were bounced 
back due to wrong email address, or due to change of the email contact due to relocation or may be some other reasons. This left 51 possible responders'. Hence the response of 22 (12 from the Portuguese version and 10 from the English version) out of 51 responders' is $43 \%$ and the response rate is accepted as an average response rate (The University of Texas at Austin, 2011).

Firstly, the characteristics of the surveyed SMEs are being mapped according to general characteristics, financial characteristics and characteristics of innovation patterns. Table- 1 shows the dependent and independent variables of those characteristics. Secondly, while mapping general characteristics, three variables are being mapped, such as the type of company, number of employees, and the sector of the company. Thirdly, to map the financial characteristics, investment made on new products, and turnover coming from new products are being considered, and fourthly, mapping innovative characteristics twelve dependent variables were considered (see table-3).

Thereafter, to learn about the prevailing situation that is challenging for the operating SMEs, four features have been taken into account, such as human aspects, constraints faced by general and political situations, and constraints generated by the globalization and competitions, which are being discussed in the next section.

Table-3: Mapping parameters to learn about the characteristics of the surveyed SMEs.

\begin{tabular}{|c|c|c|c|c|}
\hline \multicolumn{2}{|r|}{ General Characteristics } & \multicolumn{2}{|c|}{ Financial Characteristics } & Innovative Characteristics \\
\hline \multirow{3}{*}{$\begin{array}{l}\text { Type of } \\
\text { company }\end{array}$} & a non profit company: foundations, associations, semi-government & \multirow{6}{*}{$\begin{array}{l}\text { Investment on } \\
\text { new products }\end{array}$} & zero percent & Joint Venture Capital \\
\hline & a subsidiary of another company & & between $1-5$ percent & Collaboration with the University \\
\hline & an independent company & & Between 6-10 percent & Collaboration with other partmers \\
\hline \multirow{4}{*}{$\begin{array}{l}\text { Number of } \\
\text { employees }\end{array}$} & 1-9 persons employed & & \begin{tabular}{|l|} 
Between $11-15$ percent \\
\end{tabular} & Collaboration with an intermediary \\
\hline & $10-49$ persons employed & & \begin{tabular}{|l|} 
Between $16-20$ percent \\
\end{tabular} & \begin{tabular}{|l|} 
Sale out Intellectual Property \\
\end{tabular} \\
\hline & 50-249 persons employed & & \begin{tabular}{|l|}
$\begin{array}{l}\text { No new or improved } \\
\text { product }\end{array}$ \\
\end{tabular} & Sale out Patent \\
\hline & $250+$ persons employed & \multirow[t]{18}{*}{$\begin{array}{l}\text { Tumover from } \\
\text { new products }\end{array}$} & zero percent & Sale out Trademark \\
\hline \multirow[t]{17}{*}{$\begin{array}{l}\text { Sector of } \\
\text { company }\end{array}$} & $\begin{array}{l}\text { Agriculture (growing of corps; farming of poultry, animal), hunting and } \\
\text { forestry }\end{array}$ & & between $1-5$ percent & Sale out Copyright \\
\hline & Fishing & & \begin{tabular}{|l|} 
Between 6-10 percent \\
\end{tabular} & Buy in Intellectual Property \\
\hline & Mining and quarrying of energy or non-energy producing materials & & \begin{tabular}{|l|} 
Between $11-15$ percent \\
\end{tabular} & Buy in Patent \\
\hline & $\begin{array}{l}\text { Manufacturing (food products, beverages \& tobacco; textile \& textile } \\
\text { products; apparel, leather \& wood products; paper, publishing \& } \\
\text { printing; chemical \& pharmaceutical products; machinery \& equipment) }\end{array}$ & & Between $16-20$ percent & Buy in Trademark \\
\hline & Electricity, gas and water supply & & \multirow[t]{13}{*}{$\begin{array}{l}\text { No new or improved } \\
\text { product }\end{array}$} & \multirow[t]{13}{*}{ Buy in Copyright } \\
\hline & Construction & & & \\
\hline & $\begin{array}{l}\text { Wholesale and retail trade; repair of motor vehicle, motorcycles and } \\
\text { personal and household goods }\end{array}$ & & & \\
\hline & Hotels and restaurants & & & \\
\hline & $\begin{array}{l}\text { Transport (land, water, air, travel agencies), storage and communication } \\
\text { (post \& telecommunication) }\end{array}$ & & & \\
\hline & Financial intermediation (banking, leasing, insurance, brokering) & & & \\
\hline & $\begin{array}{l}\text { Real estate, renting (machinery \& equipment) and business activities (IT } \\
\text { related; R\&D; consultancy; Legal, accounting \& auditing; other business } \\
\text { activities) }\end{array}$ & & & \\
\hline & Education & & & \\
\hline & Health and social work & & & \\
\hline & Other community, social and personal service activities & & & \\
\hline & Activities of households & & & \\
\hline & Extra-territorial organization and bodies & & & \\
\hline & Other (please specify) & & & \\
\hline
\end{tabular}

\section{Some Preliminary Results}

Based on the pilot survey where 20 respondents have successfully registered their data through the web link. Table- 4 shows the top five barriers among eight on human aspects, table-5 illustrates the top seven barriers in terms of general constraints among the eleven, table- 6 shows top five policy constraints among eight, and table-7 illustrates the top six constraints in terms of competition. 
Table-4: Challenges in terms of human aspect

\begin{tabular}{|l|r|r|r|}
\hline \multicolumn{1}{|c|}{ Challenges } & Mean** & n & \multicolumn{1}{c|}{$\begin{array}{c}\text { response } \\
\text { rate \% }\end{array}$} \\
\hline Scarcity of skilled manpower & 3.60 & 8 & 44.44 \\
\hline Wage levels too expensive & & 5 & 27.77 \\
\hline Low image of the profession & & 2 & 11.11 \\
\hline Unpleasant work & & 2 & 11.11 \\
\hline Low image of the type of enterprise & & 1 & 5.55 \\
\hline
\end{tabular}

* it is the mean response rate that indicates the respondents behavior pattern, though much not significant at this stage, but with higher response rates the mean value is expected to be much higher.

Our finding and interpretation on challenges in terms of human aspects: With high wage level, scarcity of skilled manpower remains as the major two challenges in this area.

Table-5: General Constraints of Open innovation

\begin{tabular}{|c|c|c|c|}
\hline Constraints & Mean & $\mathbf{n}$ & $\begin{array}{c}\text { response } \\
\text { rate } \%\end{array}$ \\
\hline Lack of skilled manpower & 2.85 & 5 & 25.00 \\
\hline $\begin{array}{l}\text { Lack of market demand (Low purchasing power of custom- } \\
\text { er) }\end{array}$ & & 4 & 20.00 \\
\hline Problems with access to finance (other than interest rates) & & 3 & 15.00 \\
\hline Too expensive manpower & & 2 & 10.00 \\
\hline Lack of quality management personnel & & 2 & 10.00 \\
\hline $\begin{array}{l}\text { Problems with infrastructure (e.g., electricity, gas, communi- } \\
\text { cation, etc.) }\end{array}$ & & 2 & 10.00 \\
\hline Difficult to protect intellectual property & & 2 & 10.00 \\
\hline
\end{tabular}

Our finding and interpretation on challenges in terms of General Constraints of Open innovation: Added to the lack of skilled manpower as a general constraint, due to the prevailing economic crisis low purchasing power of the customer (from the demand side) and problems in accessing finance (from the supply side) are major challenges.

Table-6: Policy Constraints to Open Innovation

\begin{tabular}{|l|r|r|r|}
\hline \multicolumn{1}{|c|}{ Constraints } & \multicolumn{1}{c|}{ Mean } & n & \multicolumn{1}{c|}{$\begin{array}{c}\text { response } \\
\text { rate \% }\end{array}$} \\
\hline High cost of open innovation & 2.60 & 4 & 30.77 \\
\hline Lack of financing & & 3 & 23.07 \\
\hline Lack of information on market & & 2 & 15.38 \\
\hline Organizational rigidities & & 2 & 15.38 \\
\hline Government regulations & & 2 & 15.38 \\
\hline
\end{tabular}

Our finding and interpretation on challenges in terms of Policy Constraints of Open innovation: As usual, for SMEs the high cost of open innovation restricts them in funding this sort of projects or activities. Furthermore, financial capacity, updated information about the market, and government regulations matter to take initiatives in this aspect. 
Table-7: Actions/ Activities to compensate the barriers related to competition

\begin{tabular}{|l|r|r|r|}
\hline \multicolumn{1}{|c|}{ Activities } & Mean & n & \multicolumn{1}{c|}{$\begin{array}{c}\text { response } \\
\text { rate \%o }\end{array}$} \\
\hline Increase product differentiation & 4.83 & 7 & 24.13 \\
\hline Look for market niches (demand) & & 5 & 17.24 \\
\hline Forming strategic partnerships & & 5 & 17.24 \\
\hline Look for other foreign markets & & 5 & 17.24 \\
\hline Increase quality of product/service & & 4 & 13.79 \\
\hline Increase marketing activity & & 3 & 10.34 \\
\hline
\end{tabular}

Our finding and interpretation on actions or activities to compensate the barriers related to competition: Increased product differentiation seems to be the mostly accepted actions to compensate the barriers. Looking for a niche market (either locally or internationally), including making strategic partnership are other activities they are taking to tackle the challenges.

\section{Discussions and Future Discourse}

As a newly emerged field of research, open innovation for SME development deserves a prolonged and strategically developed qualitative and quantitative synthesis on available resources, including conceptual approaches, strategy approaches, business models and business practices. Furthermore, while developing an open innovation business model, one should look into the detail of the fundamentals of the innovation process, including the innovation channel, the turn over and also looking into the organizational and cultural differences (Rahman, 2010). Inclusive of above challenges, open innovation for SMEs also deserves further emphasize in resolving issues, like sales, licenses, cash flow, and trust in business relationship; to fulfill the grass roots clientele base by understanding their demand; to develop a transparent business model that add value to it; and to combine appropriate knowledge and technology for building a pipeline of opportunities, enabling a broad-based B2B networking through sustainable organic growth (Rahman \& Ramos, 2010).

In terms of developing an alternative approach to innovation, open innovation provides a novel explanation for various anomalies in taking challenges like expenditure in venture capital investments, intellectual property management, accepting challenges from totally unfamiliar market, or emerging issues in the face of the economic crisis. Hence, further research need to validate approaches in this aspect. Today, in spite of, open innovation has changed its status from the research interest of a few to a mainstream research area, but it lacks in many other countries that are in lagging in tackling the challenges. Further, initiated by a few scholars in the field of technology and innovation management, it is currently taken over by the entire arena of enterprise, general management and organization learning. However, there are the questions, will remain to be taken cared by the future researchers, such as: How far this format of open innovation will go and how long will it last? Will it lead to a real impetus to SMEs in need (though researchers are naming it as a paradigm shift), or will the open innovation applications be irreversible and really differ from fashion and science hypes in terms of its long-term impact thus improvising real value (Gassmann, Enkel and Chesbrough, 2010). Hence, as evident, the future remains to be seen as how much the benefit could reach out to the SMEs, and how far they could be open to these open innovation approaches.

\section{Conclusion}

In terms of mapping the challenges, this study finds that high wage level is creating scarcity of skilled manpower, which is in effect creating lack of skilled resources and at the same time creating problems in enabling purchasing power due to the prevailing economic crisis; and high cost 
of innovation including knowledge about OI strategies remain as other challenges to the SMEs. However, the important aspect of this study was also to find the actions or activities that are the SMEs taking to tackle the challenges. In this aspect, this study finds that mainly they are engaged in product differentiations, looking for partnerships and also looking for other foreign markets. These findings will assist this research to carry further in-depth study while doing the extended survey.

Furthermore, as evident, this study finds that in spite of being the largest number of entrepreneurs in almost all economies (Laursen and Salter, 2006), there are not many studies that incorporate open innovation policies on SMEs. This study also finds that, despite of contacting 51 companies, whom are informed to be SMEs, the responded data shows that a majority of the respondents (45\%) have over 250 employees, which means that they do not belong to the sector of SMEs. This also signifies that SMEs are either shy to respond to reveal their information, or they are not much aware of OI strategies (and their adoption or challenges), or especially in this period of economic crisis they are busy otherwise than responding to any queries (fighting for their survival). Hence, this research suggests approaching a newly collected list of companies for another round of extended survey, and if possible approaching those respondents (need to approach all 51, as the survey was anonymous, making a challenge to this research) of the pilot survey to gather knowledge about those SMEs, and at the same time try to improve their performance through a web-enabled tool. Finally, introduction of some more scientifically approved instruments could be added to the current instruments to find out further aspects of SMEs under this study.

\section{Acknowledgement}

This work is funded by FEDER funds through the Operational Programme for Competitiveness Factors - COMPETE and National Funds through FCT - Foundation for Science and Technology under the Project: FCOMP-01-0124-FEDER-022674

\section{References}

Abulrub, A. G., \& Lee, J. (2011). Open innovation management: Challenges and prospects, International Conference on Leadership, Technology, and Innovation Management (ICLTIM), December 2-4, 2011, Istanbul, Turkey.

Ashurst, C., Freer, A., Ekdahl, J., \& Gibbons, C. (2012). Exploring IT-enabled innovation: A new paradigm? International Journal of Information Management. 32(4), 326-336. Available at http://dx.doi.org/10.1016/j.ijinfomgt.2012.05.006

Caetano, M., \& Amaral, D. C. (2011). Roadmapping for technology push and partnership: A contribution for open innovation environments. Technovation, 31, 320-335.

Cardoso, G., Roldão, V., Espanha, R., \& Castro, D. (2009). Entrepreneurism and innovation in SMEs in Portugal. The COTEC SME Network, LINI Working Paper No. 4, Lisbon Internet and Networks.

Chesbrough, H. (2003). Open innovation: The new imperative for creating and profiting from technology. Boston, MA: Harvard Business School Publishing.

Chesbrough, H. W. (2006). Open business models: How to thrive in the new innovation landscape. Boston, MA: Harvard Business School Press.

Chesbrough, H., Vanhaverbeke, W. \& West, J. (2006). (Eds). Open innovation: Researching a new paradigm. Oxford University Press: London.

Chiang, Y.-H., \& Hung, K.-P. (2010). Exploring open search strategies and perceived innovation performance from the perspective of inter-organizational knowledge flows. R\&D Management, 40(3), 292299.

Dahlander, L., \& Gann, D. M. (2010). How open is innovation? Research Policy, 39, 699-709. 
De Jong, J. P. J., Vanhaverbeke, W., Kalvet, T., \& Chesbrough, H. (2008). Policies for open innovation: Theory, framework and cases. Research project funded by VISION Era-Net, Helsinki: Finland.

Elton, J. J., Shah, B. R., \& Voyzey, J. N. (2002). Intellectual property: partnering for profit. McKinsey Quarterly Special Edition Technology, 4, 59-67.

Enkel, E., Gassmann, O. \& Chesbrough, H. (2009). Open R\&D and open innovation: exploring the phenomenon. $R \& D$ Management, 39(4), 311-316.

European Commission. (2003). The new SME definition: User guide and model declaration. Enterprise and Industry Publications, European Commission.

European Commission. (2008). SBA fact sheet Portugal. European Commission: Enterprise and Industry, European Commission.

$\mathrm{Fu}, \mathrm{X}$. (2012). How does openness affect the importance of incentives for innovation? Research Policy, 41, $512-523$.

Gassmann, O., Enkel, E., \& Chesbrough, H. (2010). The future of open innovation. R\&D Management, $40(3), 213-222$.

Gredel, D., Kramer, M., \& Bend, B. (2011). Patent-based investment funds as innovation intermediaries for SMEs: In-depth analysis of reciprocal interactions, motives and fallacies. Technovation, 32(9-10), 536549. doi:10.1016/j.technovation.2011.09.008

Huang, Z. (2011). SME strategic management and innovation-A comparative study between Finland and China. Proceedings of the Sustainable Innovation, Entrepreneurship and Growth, Stockholm, Sweden, June 15-18

Jaruzelski, B., \& Dehoff, K. (2008). Beyond borders: The global innovation 1000. Strategy+business, 53(Winter), 54-67.

Kapurubandara, M., \& Lawson, R. (2006, December 09). Barriers to adopting ICT and e-commerce with SMEs in developing countries: An exploratory study in Sri Lanka. CollECTeR '06, Adelaide, Australia.

Laursen, K., \& Salter, A. (2006). Open for innovation: The role of openness in explaining innovation performance among UK manufacturing firms. Strategic Management Journal, 27, 131-150.

Lee, S., Park, G., Yoon, B., \& Park, J. (2010). Open innovation in SMEs - An intermediated network model. Research Policy, 39(2), 290-300.

Lichtenthaler, U. (2005). External commercialization of knowledge: Review and research agenda. International Journal of Management Reviews, 7, 231-255

Morgan, E. J., \& Crawford, N. (1996).Technology broking activities in Europe-A survey. International Journal of Technology Management, 12, 360-367.

Peres, W., \& Stumpo, G. (2000): Small and medium-sized industrial enterprises in Latin America and the Caribbean under the new economic model. World Development, 28(9). Oxford, U.K., Pergamon Press Ltd.

Rahman, H. (2010) Open innovation: Opportunities and challenges for SMEs. In M. M. Cruz-Cunha \& J. Varajão (Eds.), E-business issues, challenges and opportunities for SMEs: Driving Competitiveness (pp. 87-100). IGI Global.

Rahman, H., \& Ramos, I. (2012a). Empowerment of SMEs: Through open innovation strategies: Life cycle of technology management. In S. Chhabra (Ed.), ICT influences on human development, interaction and collaboration (pp. 185-201). IGI Global.

Rahman, H., \& Ramos, I. (2012b, June 22-27). Open Innovation in Entrepreneurships: Agents of Transformation towards the Knowledge-Based Economy. Proceedings of the Informing Science and Information Technology Education Conference (I $I^{n}$ SITE), Montreal, Canada. 
Rahman, H., \& Ramos, I. (2012c). Open innovation in SMEs of developing and transitional economies. In K. M. Rezaul (Ed.), Strategic and pragmatic e-business: Implications for future business practices (pp. 377-395). Hershey, PA: Business Science Reference.

Rohrbeck, R., Hölzle, K., \& Gemünden, H. G. (2009). Opening up for competitive advantage - How Deutsche Telekom creates an open innovation ecosystem. $R \& D$ Management, 39(4), 420-430.

Saguy, S. I. (2011). Academia-industry innovation interaction: Paradigm shifts and avenues for the future. Procedia Food Science, 1, 1875 - 1882.

Saini, D. S., \& Budhwar, P. S. (2008). Managing the human resource in Indian SMEs: The role of indigenous realities. Journal of World Business, 43, 417-434.

Schmid, B., Stanoevska-Slabeva, K., \& Tschammer. V. (2001). Towards the ESociety: E-Commerce, EBusiness, E-Government. Zurich, Switzerland, 13 October.

Smallbone, D., North, D., \& Vickers, I. (2003). The role and characteristics of SMEs in innovation. In B. T. Asheim, A. Isaksen, C. Nauwelaers, \& F. Tödtling (Eds.), Regional innovation policy for smallmedium enterprises (pp. 3-20). Cheltenham: Edward Elgar.

Statistics Portugal. (2010, 28 June). Structural business statistics studies 2008.

Statistics Portugal. (2011, 30 June). Structural business statistics studies 2007-2009.

Tushman, M., \& Nadler, D. (1986). Organizing for innovation. California Management Review, 28(3), 7492.

The University of Texas at Austin. (2011). Response rates. Retrieved from http://www.utexas.edu/academic/ctl/assessment/iar/teaching/gather/method/survey-Response.php

U.S. Small Business Administration. (n.d.). Small business size standards. Retrieved from http://www.sba.gov/category/navigation-structure/contracting/contracting-officials/eligibility-sizestandards

Van de Vrande, V., de Jong, J.P.J., Vanhaverbeke, W. \& de Rochemont, M. (2008). Open innovation in SMEs: Trends, motives and management challenges, a report published under the SCALES-initiative (SCientific AnaLysis of Entrepreneurship and SMEs), as part of the 'SMEs and Entrepreneurship programme' financed by the Netherlands Ministry of Economic Affairs, Zoetermeer, November 2008.

Van de Vrande, V., de Jong, J. P. J., Vanhaverbeke, W., \& de Rochemont, M. (2009). Open innovation in SMEs: Trends, motives and management challenges. Technovation, 29(6-7), 423-437.

Young, B., Hewitt-Dundas, N., \& Roper, S. (2008). Intellectual property management in publicly funded R\&D centres-A comparison of university-based and company-based research centres. Technovation, $28,473-484$.

\section{Appendix}

\section{Survey of SMEs to Acquire Knowledge on Their Current Status of Entrepreneurship and Open Innovation Questionnaire}

\section{PART- A. General characteristics}

(Nature and Sector of Business with the Company size)

\section{How would you characterize your company? Is it ...}

a non profit company: foundations, associations, semi-government

a subsidiary of another company

an independent company 
2. How many employees are being employed?

1-9 persons employed

10-49 persons employed

50-249 persons employed

$250+$ persons employed

3. Which sector your company belongs?

A Agriculture, hunting and forestry

B Fishing

C Mining and quarrying

D Manufacturing

E Electricity, gas and water supply

F Construction

G Wholesale and retail trade; repair of motor vehicle, motorcycles and personal and household goods

$\mathrm{H}$ Hotels and restaurants

I Transport, storage and communication

$\mathrm{J}$ Financial intermediation

$\mathrm{K}$ Real estate, renting and business activities

$M$ Education

$\mathrm{N}$ Health and social work

O Other community, social and personal service activities

P Activities of households

Q Extra-territorial organization and bodies

\section{PART-B. Financial Characteristics}

(To learn about the investment pattern and turnover or annual sale of the surveyed companies)

4. In terms of investment for any new or innovative product (if you consider it will fall under the open innovation category), how much of your investment do you invest?

zero percent

between 1-5 percent

between 6-10 percent

between 11-15 percent

between 16-20 percent

no new or improved product

5. Could you please estimate the percent of turnover (annual sales) coming from new or significantly improved products or services (those you consider that falls under open innovation category) in the last two years?

Zero percent

Between 1-5 percent

Between 6-10 percent

Between 11-15 percent

Between 16-20 percent

No new or improved product 


\section{PART-C. Human Resources as an input to Open innovation}

(Learn about the human resource problem in your company)

6. What is your main recruiting problem? (Click/select two most frequently faced difficulties)

Scarcity of skilled manpower

Scarcity of non-skilled manpower

Low image of the profession

Low image of the sector

Low image of the type of enterprise

Wage levels too expensive

Unpleasant work

Unpleasant working conditions

No problem with recruiting

Does not apply (for 1 person firms)

\section{PART-D. General Constraints of Open innovation in an enterprise}

(To learn about constraints related to managerial, policy, competition and open innovation issues)

7. Did your company encounter any of the following constraints in the last two years (General Constraints to Open Innovation)? (Select more than one)

Lack of market demand (Low purchasing power of customer)

Lack of skilled manpower

Too expensive manpower

Lack of quality management personnel

Problems with administrative regulations

Problems with infrastructure (e.g., electricity, gas, communication, etc.)

Problems with access to finance (other than interest rates)

High interest rates

Lack of knowledge in implementing new form of technology

Lack of knowledge in implementing new form of organization

Difficult to protect intellectual property

Did not have any open innovation plan

Other (please specify)

8. What was/were the main constraints you think in terms of open innovation activities in your company during last two years? (Policy Constraints to Open Innovation)(Select the two most constraints)

High cost of open innovation

Lack of financing

High economic risk

Organizational rigidities

Government regulations

Lack of customers' responsiveness 
Lack of knowledge to use new technology

Lack of information on market

Did not have any innovative plan

None of the above

\section{If competition becomes heavier and profit margin becomes lower in your main market, what actions do you take to compete? (Competition related to Open Innova- tion) (Select more than one)}

Increase quality of product/service

Increase product differentiation

Look for market niches (demand)

Increase marketing activity

Reduce costs of production

Forming strategic partnerships

Reduce prices (prices of products/services)

Increase working hours

Look for other foreign markets

Reduce production

\section{Biographies}

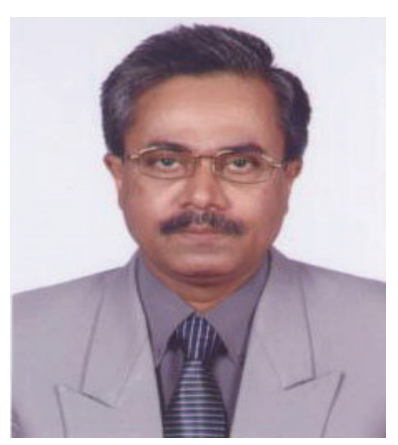

Hakikur Rahman is an academic over 27 years has served leading education institutes and established various ICT4D projects funded by ADB, UNDP and World Bank in Bangladesh. He is currently serving as a Post Doctoral Researcher at the University of Minho, Portugal under the Centro Algoritmi. He has written and edited over 25 books, more than 50 book chapters and contributed over 100 articles on computer education, ICTs, knowledge management, open innovation, data mining and e-government research in newspapers, journals and conference proceedings. Graduating from the Bangladesh University of Engineering and Technology in 1981, he has done his Master's of Engineering from the American University of Beirut in 1986 and completed his PhD in Computer Engineering from the Ansted University, BVI, UK in 2001.

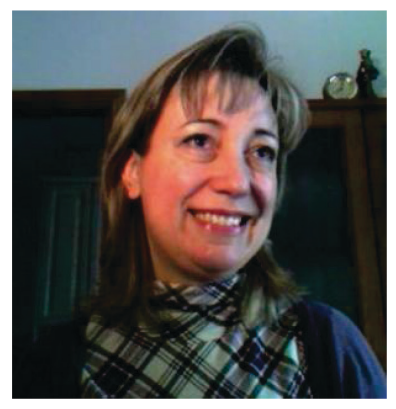

Isabel Ramos is an Assistant Professor at Information Systems Department of University of Minho, Portugal. She coordinates a research group in Knowledge Management. She also has research work in the field of Requirements Engineering. Isabel Ramos is associate editor of the International Journal of Technology and Human Interaction and Secretary of the IFIP TC8 (Information Systems). Her research and teaching interests include: requirements engineering, knowledge management, organizational theory, sociology of knowledge, history of science, research methodology. She is responsible for the user studies in two funded R\&D projects. Isabel Ramos is author of more than three dozen scientific papers presented at international conferences and published in scientific and technical journals. She advises the work of several PhD and Master students. 
${ }^{\mathrm{i}}$ In India, the industrial sector has two broad segments, such as the Small Scale Industries (SSI) and Others (medium and large industries). The Government of India notifies the definition of small-scale industry from time to time based on the investment ceiling. The present definition is, "an industry in the small scale sector shall have investment in plant and machinery not exceeding INR 10 million" (approx. US\$22,000). A subcomponent of micro enterprises, known as the "Tiny Sector" forms part of the overall SSI sector. Medium sized industries are out of the scope. India, thus, follows the concept of SSIs and not SMEs.

${ }^{i i}$ In India, until recently there has been no formal concept of SME or medium enterprises. However, the term small scale industry (SSI) is well known; this is different from the SME sector in other countries. The Government of India had a policy of providing assistance of different types to SSIs through various state agencies. Lately, Indian Parliament has enacted the Micro, Small and Medium Enterprises Development Act, 2006.1 As per this Act, medium manufacturing or production enterprises are those which have an investment in plant and machinery between Rs. 50 million and 100 million (1\$ US = Rupees 40.10 approximately in July 2007). The investment referred to in this definition is that in "initial fixed assets" i.e., the plant and machinery (which excludes land \& building). Under this Act, a micro enterprise has been defined as one where the investment in plant and machinery does not exceed Rs. 2.5 million and a small enterprise as one where such investment is more than Rs. 2.5 million but does not exceed Rs. 50 million. Whereas, a medium enterprise is one in which the investment limit is between Rs. 50 million and Rs. 100 million. In this Act there is no reference to the term SME. One may, however, combine the definitions of small and medium enterprises to derive a concept of SME. This would mean that an SME in the Indian context is an enterprise in which the investment in plant and machinery is between 2.5 million and 100 million.2 The definition of the terms "small" and "medium" enterprise in India is investment specific, while in the rest of the world it reflects a combination of factors including terms of employment, assets or sales or combination of these factors (Saini \& Budhwar, 2008). 